\title{
ENDOTOXINEMIA IN ANTIVIRAL THERAPY FOR CHRONIC HEPATITIS C AND ITS POTENTIAL PHARMACOLOGIC CORRECTIONS
}

\author{
Geyvandova N. I., Yagoda A. V., Bondarenko E. M.
}

\author{
Stavropol State Medical University, Russian Federation
}

C hronic hepatitis $\mathbf{C}$ (CHC) is a serious medical and social issue. This ailment is associated with a high morbidity rate, possible hepatic cirrhosis and hepatocellular carcinoma $[8,21]$.

The gold standard in treating chronic hepatitis $C$ is combined antiviral therapy (AVT) with pegylated interferon-alpha (PEG-IFN $\alpha$ ) in combination with Ribavirin. At the same time, AVT produces numerous adverse events ( $A E$ ) that pose considerable difficulties both to the doctor and to the patient. Haematologic disturbances of various intensity manifested as anemia, neutropenia, and thrombocytopenia, are among the leading AE coming along with antiviral therapy [10, 14]. Of this side effect, neutropenia has been studied in fewer details, especially when it comes to the clinical relevance of its negative implications. In case of PEG-IFN $\alpha$ treatment the likelihood of developing neutropenia is $17-34 \%$, which is higher than in case of short-acting IFN $\alpha$ administration. This could be related to a longer effect PEG-IFN $\alpha$ has on the bone marrow [6, $7,12]$. IFN $\alpha$ causes neutropenia due to both direct myelotoxicity and induced autoimmune response [15].

A consequence of neutropenia developing in patients undergoing AVT could be increased serum levels of endotoxin. In 1952, O. Westphal and O. Luderitz succeeded in decoding the biochemical formula of endotoxin and set the terms endotoxin and lipopolyssacharide (LPS) equal [18]. The dominant cellular acceptors for LPS in blood are polymorphonuclear leukocytes, macrophages, and platelets. Human granulocytes are an important endotoxin-binding system involved in complex processes connected to immobilization, transport and removing LPS from the body. Endotoxin binding with granulocytes and macrophages induces, on the one hand, the development of protective me-

Geyvandova Natalya, MD, PhD,

Professor, Department of Hospital Therapy,

Stavropol State Medical University;

tel.: 89624452246; e-mail: ngeyvandova@yandex.ru

Yagoda Alexander, MD, PhD, Professor,

Head of Department of Hospital Therapy,

Stavropol State Medical University;

tel.: 89064907330; e-mail: alexander.yagoda@gmail.com

Bondarenko Ekaterina, MD, Assistant Lecturer, Department of Hospital Therapy, Stavropol State Medical University; tel.: 89188600180; e-mail: katrinbondarenko@yandex.ru chanisms network, while on the other - production of cytokines and cytokine mediated destruction of various organs and tissues [2, 19]. Therefore, increased levels of endotoxin against the developing neutropenia may suppress significantly the protective capacity of the immune system. However the clinical significance of endotoxinemia elevated indicators in case of AVT has not been detected yet, nor have its potential negative effects.

The purpose of the study is to investigate the serum levels of endotoxin against neutropenia in patients with $\mathrm{CHC}$ who undergo antiviral therapy, as well as detecting pharmacologic corrections for endotoxinemia.

Material and Methods. The course of neutropenia through AVT was investigated in 101 patients diagnosed with chronic hepatitis C - 38 females and 63 males. The age varied from 18 to 62 (37.6 $\pm 0.7 \mathrm{yrs}) .62$ of the patients $(61.4 \%)$ had HCV genotype 1 infection while others revealed non-1 (HCV genotypes 2 and 3). The average level of viremia was $4.9 \pm 1.2 \log 10$. None of the patients was diagnosed with any hepatic cirrhosis stage.

In all the patients the combined AVT was administered with IFN- $\alpha$ and Ribavirin. Of them 83 patients were given PEG-IFN- $\alpha-2$ a (Pegasys), while another 18 - short-acting IFN- $\alpha$. The duration of the therapy depended on the HCV genotype - 24 weeks in case of HCV genotypes 2 and 3, and 48 weeks in case of HCV genotype 1.

The serum levels of endotoxin were detected with chromogenic assay (Hbt LAL Hycult Biotech, Netherlands). The control group included 20 healthy volunteers aged 21-42 yrs.

The results obtained were processed using Microsoft Excel, Biostat, and STATISTICA 6.0. The comparative analysis of the parameters in groups with normal distribution was done using Student's t-test; for groups with non-normal distribution Mann-Whitney test. Spearman's rank correlation coefficient was employed to reveal the correlation dependence.

Results and Discussion. The total number of leukocytes and the number of neutrophils prior to the antiviral therapy were within the normal ranges. There is data saying that patients with hepatitis $\mathrm{C}$ initially have a lower count of neutrophils if compared to the control group [5]. At the same time the level of neutrophils below 2900 cells $/ \mathrm{mcl}$ at the start of 
the therapy was recommended as a predictor of severe neutropenia during treatment [11].

In two weeks of AVT already the number of neutrophils went down reaching the minimum by Week 12, after which the level of neutropenia remained stable until Week 24 . However, in patients with HCV genotype 1 the level of neutrophils on Week 48 was lower than on Week $24(p=0.015)$. In the course of antiviral therapy, 62 patients developed grade 2 neutropenia $\left(<1.5 \times 10^{9} / \mathrm{I}\right)(54$ patients who were treated with Pegasys, and 8 - with short-acting IFN- $\alpha$ ). Neutrophil count reduction (grade 3 neutropenia) $<1.0 \times 10^{9} /$ I through the course of AVT was more often observed in case of using pegylated drug (28.5\%), rather than when employing short-acting IFN- $\alpha$ (8\%; $p=0.001)$. There was no dependence observed of neutropenia development on sex or age. At the same time literature contains evidence of direct relation between age and neutropenia developing through AVT, which was the case, in particular, with patients aged over 60 [13].

Prior to AVT the patients with $\mathrm{CHC}$ had blood levels of endotoxin no different from those in healthy people. The endotoxin indices revealed no dependence on the patients' sex or age. Through the course of AVT against developing neutropenia, from Week 8 on, there was an increase in the blood endotoxin levels observed in all the patients (Table 1). Increased endotoxinemia remained there up until the end of the treatment. During that, in the cases with neutropenia (the number of cells $<1.5 \times 10^{9} / \mathrm{I}$ ) the endotoxin levels were significantly higher than in patients with no neutropenia (Table 2). The significance of this difference in groups demonstrating different levels of neutrophils showed up on Week 8 of AVT already and remained further. An increase in the endotoxinemia given the reduction in the absolute number of neutrophils is a perfect illustration of endotoxin-neutralizing capacity found in granulocytic cells. This dependence could be proven through an inverse relationship we detected between the endotoxin levels and the number of neutrophils $(\mathrm{Rs}=-0.74)$.

Table 1

Endotoxin levels $(\mathrm{U} / \mathrm{ml})$ in blood of patients with $\mathrm{CHC}$ undergoing antiviral therapy $\mathrm{Me}(\mathbf{Q} 1 ; \mathbf{Q} 3)$

\begin{tabular}{|l|c|c|c|c|c|c|}
\hline & $\begin{array}{c}\text { Prior to } \\
\text { treat- } \\
\text { ment }\end{array}$ & $\begin{array}{c}4 \\
\text { weeks }\end{array}$ & $\begin{array}{c}8 \\
\text { weeks }\end{array}$ & $\begin{array}{c}12 \\
\text { weeks }\end{array}$ & $\begin{array}{c}24 \\
\text { weeks }\end{array}$ & $\begin{array}{c}48 \\
\text { weeks }\end{array}$ \\
\hline $\begin{array}{l}\text { Control } \\
(\mathrm{n}=20)\end{array}$ & $\begin{array}{c}0.15 \\
(0.016 ; \\
0.68)\end{array}$ & & & & & \\
\hline $\begin{array}{l}\mathrm{CHC} \\
(\mathrm{n}=101)\end{array}$ & $\begin{array}{c}3.8 \\
(0.66 ; \\
15.9)\end{array}$ & $\begin{array}{c}5.2 \\
(0.615 ; \\
3.212)\end{array}$ & $\begin{array}{c}9.9 \\
(3.528 ; \\
22.7)\end{array}$ & $\begin{array}{c}16.6 \\
(1.3 ; \\
30.1)\end{array}$ & $\begin{array}{c}15.65 \\
(1.7 ; \\
30.4)\end{array}$ & $\begin{array}{c}10.5 \\
(0.56 ; \\
13.3)\end{array}$ \\
\hline $\mathrm{P}_{1}$ & 0.00031 & 0.02 & 0.004 & 0.006 & 0.05 & 0.006 \\
\hline $\mathrm{P}_{2}$ & & 0.10 & 0.006 & 0.003 & 0.007 & 0.02 \\
\hline
\end{tabular}

$\mathrm{P}_{1}$ - compared to healthy people; $\mathrm{P}_{2}-$ compared to indices before treatment
Table 2

Endotoxin levels $(\mathrm{U} / \mathrm{ml})$ in blood of patients with $\mathrm{CHC}$ undergoing antiviral therapy depending on neutropenia development $\mathrm{Me}(\mathbf{Q} 1 ; \mathbf{Q 3 )}$

\begin{tabular}{|l|c|c|c|c|c|c|}
\hline & $\begin{array}{c}\text { Prior to } \\
\text { treat- } \\
\text { ment }\end{array}$ & $\begin{array}{c}4 \\
\text { weeks }\end{array}$ & $\begin{array}{c}8 \\
\text { weeks }\end{array}$ & $\begin{array}{c}12 \\
\text { weeks }\end{array}$ & $\begin{array}{c}24 \\
\text { weeks }\end{array}$ & $\begin{array}{c}48 \\
\text { weeks }\end{array}$ \\
\hline $\begin{array}{l}\text { Patrients } \\
\text { with } \\
\text { neutropenia } \\
\text { (n=62) }\end{array}$ & $\begin{array}{c}5.5 \\
(0.71 ; \\
20.45)\end{array}$ & $\begin{array}{c}6.764 \\
(1.094 ; \\
20.2)\end{array}$ & $\begin{array}{c}20.7 \\
(6.6 ; \\
30)\end{array}$ & $\begin{array}{c}2.25 \\
(0.615 ; \\
27.65)\end{array}$ & $\begin{array}{c}8 \\
(0.59 ; \\
30.1)\end{array}$ & $\begin{array}{c}11.3 \\
(1.735 ; \\
15.75)\end{array}$ \\
\hline $\begin{array}{l}\text { Patrients } \\
\text { without } \\
\text { neutropenia } \\
(\mathrm{n}=39)\end{array}$ & $\begin{array}{c}2.5 \\
(0.7 ;\end{array}$ & $\begin{array}{c}0.665 \\
(0.04 ; \\
13.4)\end{array}$ & $\begin{array}{c}0.8 \\
(0.34 ; \\
3.91)\end{array}$ & $\begin{array}{c}0.92 \\
(0.3 ; \\
8.568)\end{array}$ & $\begin{array}{c}0.56 \\
(0.065 ; \\
1.34)\end{array}$ & $\begin{array}{c}0.9 \\
(0.515 ; \\
3.45)\end{array}$ \\
\hline $\mathrm{P}$ & 0.27 & 0.08 & 0.005 & 0.04 & 0.01 & 0.04 \\
\hline
\end{tabular}

There is no single shared opinion on the need to correct neutropenia in patients with $\mathrm{CHC}$ who undergo AVT. Oncological practice suggests that patients with neutropenia $<500$ cells $/ \mathrm{mcl}$ who undergo polychemotherapy need antibiotics treatment. However, neutropenia developing against AVT in the range of $1000-1500$ cells/mcl often remains not associated with bacterial complications and is not believed to need correction [6, 12, 17]. The existing standards in AVT state that in case of neutrophils going down $<750$ cells/mcl the PEG-IFN dose should be reduced by $50 \%$, while in case the index above is $<500$ cells $/ \mathrm{mcl}$ the treatment has to be discontinued. At the same time, it is noted that in $10-20 \%$ of cases neutropenia is the most common cause for reduction of the interferon dose and the frequency of sustained virologic response [6].

An alternative to interferon dose reduction is granulocyte colony-stimulating factor (G-CSF) administration, in particular Filgrastim - a recombinant human G-CSF, synthesized in an E. coli. G-CSF induces the generation and differentiation of neutrophils out of the late progenitor cells, facilitates their phagocytic activity, mobilizes hematopoietic (CD34+) cells, part of them bearing the G-CSF receptor (CD114+). There is data evidencing a defect in the synthesis of endogenous $\mathrm{G}-\mathrm{CSF}$ in patients with $\mathrm{CHC}$ undergoing AVT $[1,5]$. There are no dosing regimens available yet in relation to Filgrastim for patients receiving AVT.

28 patients who developed neutropenia $\left(<1 \times 10^{9} / \mathrm{l}-1000\right.$ cells $/ \mathrm{mcl}$ ) had Filgrastim (Neupomax) administered at an initial dose of $300 \mu \mathrm{g}$ once per week, two days before or two days after the introduction of IFN- $\alpha$. Filgrastim was introduced on Week 4 through Week 12, depending on the neutropenia development terms. Further on the dosage and the mode of administration were selected on an individual basis - 2 patients got the medicine at $300 \mu \mathrm{g}$ twice a week; 10 patients $-300 \mu \mathrm{g}$ once a week; 16 - $300 \mu \mathrm{g}$ - once every two weeks. As Filgrastim was administered the level of endotoxinemia decreased significantly $(p<0.05)$ while the patients demonstrated a better well-being status (evaluated with Beck Scale). None of those who got G-CSF had any infectious complications. Introduction of Filgrastim allowed maintaining the level of neutrophils at no lower than $1.0-1.5 \times 10^{9} / \mathrm{I}$ thus preventing the need to reduce the interferon doses. 
Reports on research projects like described above are far from being abundant. In a study run by J. Koirala et al. all the patients were treated with Pegasys, and Filgrastim was administered in case of neutropenia below 1000 cells $/ \mathrm{mcl}$, on average after $13(2-40)$ weeks, $300 \mu \mathrm{g}$ once a week, after which the dosage remained the same depending on the level of neutrophils achieved [9]. When needed the dose of Filgrastim had to be taken up to $480 \mu \mathrm{g}$, while in case of complete response it was reduced down to $150 \mu \mathrm{g}$. At the same time no patient developed any neutropenia-associated infectious complications; besides, none of those belonging to the group that was given G-CSF discontinued the antiviral therapy early. The conclusion made here is that the purpose for the therapy should be a level of neutrophils at $1000 \mathrm{cells} / \mathrm{mcl}$ and not the baseline level [9]. In another study, in case of neutropenia developing $<1000 \mathrm{cells} / \mathrm{mcl}$, the maintenance of the PEG-IFN dose against Filgrastim introduced at 150$300 \mu \mathrm{g}$ twice a week, resulted in sustained virological response (SVR) more often rather than in cases where the interferon doses were reduced: $30 \%$ vs. $21 \%$ [20].

Filgrastim, if introduced, will bring up the cost of the therapy, so some authors still remain doubtful when it comes to justifying the need for its administration. However, the level of adherence to AVT and successful outcome is higher in patients with no haematologic disturbances (58\% vs. $25 \%$ ) [11]. A pharmacoeconomic analysis has shown that G-CSF

\section{References}

1. Geyvandova N. I., Yagoda A. V., Bondarenko E. M., Rogova S. Sh. Granulocyte colonystimulating factor and neutropenia development through antiviral therapy for chronic hepatitis C (CHC). Russ. Journal of Gastroenterol., Hepatol., and Coloproctol. Volume of Fifteenth Russian Conference "Hepatology Today". 2010;1(XX):30.

2. Permyakov N. K., Yakovlev M. Yu., Galankin V. N. Endotoxin and polymorphonuclear leukocyte system. Archives of Pathology. 1989:5(51):3-11.

3. Chapko M. K., Dominitz J. A. Cost-effectiveness of growth factors during hepatitis $\mathrm{C}$ anti-viral therapy. Aliment. Pharmacol. Ther. 2006;7(24):1067-1077.

4. Davis G. L., Wong G. B., McHutchinson J. G. et al. Early virologic response to treatment with peginterferon-alfa plus ribavirin in patients with chronic hepatitic C. Hepatology. 2003;38:645-652.

5. Durante-Mangoni E., lardino P., Utili R. et al. Defective synthesis of granulocyte-colony stimulating factor in pegylated interferon-alpha treated chronic hepatitis $\mathrm{C}$ patients with declining leukocyte counts. Antivir. Ther. 2006;11(5):637-640

6. Fried M. W., Shiffman M. L., Reddy R. et al. Peginterferon alfa-2a plus ribavirin for chronic hepatitis $\mathrm{C}$ virus infection. N. Engl. J. Med. 2002;347:975-982.

7. Fukuda A., Kobayashi H., Teramura K. et al. Effects of interferon-alpha on peripheral neutrophil counts and serum granulocyte colony-stimulating factor levels in chronic hepatitis C patients. Cytokynes, cellular \& molecul. Therapy. 2000;3(6):149-154.

8. Ghany M. G., Strader D. B., Thomas D. L., Seeff L. B. Diagnosis, management and treatment of hepatitis $C$ : an update. Hepatology. 2009;49:1335-1374.

9. Koirala J., Gandotra S. D., Rao S. et al. Granulocyte Colony-Stimulating Factor Dosing in Pegylated Interferon Alpha-Induced Neutropenia and its Impact on Outcome of Anti-HCV Therapy. J. Viral. Hepat. 2007;14(11):782-787.

10. Kowdley K. V. Hematologic side effects of interferon and ribavirin therapy. J. Clin. Gastroenterol. 2005;39 (suppl. 1):3-8. taken in the dose of $300 \mu \mathrm{g}$ once a week is economically profitable when talking of patients with HCV genotype 1 and neutropenia, yet not patients with HCV genotypes 2 and 3 , especially when introduced in the first 12 weeks as this is exactly the time when forced reduction of antiviral drugs doses shall have the highest impact on the frequency of sustained virological response $[3,4]$. Mention to be made here that within this particular period we observed a reduction in the number of neutrophils and an increase in neutropenia-associated endotoxinemia.

\section{Conclusion}

1. Patients with chronic hepatitis $C$, when undergoing combined antiviral therapy, have their levels of neutrophils going down starting from Week 2 already, while the minimum counts are observed by Week 12 of the therapy. Neutropenia shall develop more often when pegylated IFN $\alpha$ is used.

2. Neutropenia developing against antiviral treatment offered to patients with $\mathrm{CHC}$ is associated with an increase in the serum levels of endotoxin. There has been an inverse relationship found between endotoxinemia and neutrophil counts in the peripheral blood.

3. Introduction of G-CSF allows stabilizing the level of neutrophils, reducing endotoxinemia, improving significantly the patients' well-being as well as their tolerance to the antiviral therapy, also preventing interferon doses reduction.

11. Lebray P., Nalpas B., Vallet-Pichard A. et al. The impact of haematopoietic growth factors on the management and efficacy of antiviral treatment in patients with hepatitis C virus. Antivir. Ther. 2005;10(6):769-776.

12. Manns M. P., McHutchison J. G., Gordon S. C. et al. Peginterferon alfa-2b plus ribavirin compared with interferon alfa- $2 \mathrm{~b}$ plus ribavirin for initial treatment of chronic hepatitis C: a randomized trial. Lancet. 2001;358:958-965.

13. Nudo C. G., Wong P., Hilzenrat N., Deschenes M. Elderly patients are at greater risk of cytopenia during antiviral therapy for hepatitis C. Can. J. Gastroenterol. 2006;20(9):589-592.

14. Patel K., Muiz A. J., McHutchison J. G. Diagnosis and treatment of chronic hepatitis C. BMJ. 2006;332:10131017

15. Peck-Radosavljevic M., Wichlas M., Homoncik-Kraml M. et al. Rapid suppression of hematopoiesis by standard or pegylated interferon-alphaet. Gastroenterol. 2002;123:141-151.

16. Sarrazin C., Hézode C., Zeuzem S., Pawlotsky J.-M. Antiviral strategies in hepatitis $\mathrm{C}$ virus infection. J. Hepatol. 2012;56(1):88-100

17. Soza A., Everhart J. E., Ghany M. J. et al. Neutropenia during combination therapy of interferon alfa and ribavirin for chronic hepatitis C. Hepatology. 2002;5(36):12731279.

18. Westphal O, Luderitz O., Galanos C et al. The story of endotoxin. Proc. 2-rd Internat. Conf. Adv. Immunopharm; 1975. P. 13-37.

19. Wheeler M. D. Stachlewitz R. F. Vamachina S. et al. Glycine-gated chloride channels in neutrophils attenuate calcium influx and superoxide production. Faseb $\mathrm{J}$. 2000;3(14):476-484.

20. Zacharakis G., Koskinas J., Sidiropoulos J. et al. G-CSF in safe and improves adherence and SVR in HCV patients with genotype 1 who develop Peg-IFNa-2b related severe neutropenia. Dig. Dis. Week. 2006;1828.

21. Zeuzem S. Interferon-based therapy for chronic hepatitis C: current and future perspectives. Nat. Clin. Pract. Gastroenterol. Hepatol. 2008;5:610-622. 


\section{ENDOTOXINEMIA IN ANTIVIRAL THERAPY FOR CHRONIC HEPATITIS C AND ITS POTENTIAL PHARMACOLOGIC CORRECTIONS \\ GEYVANDOVA N. I., YAGODA A. V., \\ BONDARENKO E. M.}

Serum levels of endotoxin were detected in 101 patients with $\mathrm{CHC}$. All the patients received combined antiviral therapy (AVT): 83 of them got PEGIFN- $\alpha-2 a$ (Pegasys) and another 18 - short-acting IFN $\alpha$.

The total number of leukocytes, neutrophils as well as the endotoxin levels in blood prior to AVT was normal. Through the course of AVT, 62 patients developed grade 2 neutropenia (54 patients on Pegasys and 8 receiving short-acting IFN $\alpha$ ). Given the developing neutropenia, starting from Week 8 on, there was an increase in the blood endotoxin observed in all the patients, while those with neutropenia had their blood endotoxin higher if compared with those with no neutropenia. There was an inverse relationship found between the endotoxin levels and the number of neutrophils. Filgrastim (Neupomax) was administered in 28 patients with neutropenia $<1.0 \times 10^{9} /$ l. Against the Filgrastim treatment the endotoxinemia indices got down significantly $(p<0.05)$, while the patients were demonstrating an improved well-being status. Introduction of Filgrastim allowed maintaining the neutrophil level at no lower than $1.0-1.5 \times 10^{9} /$ I thus preventing the need to reduce the doses of interferon.

Key words: chronic hepatitis C, neutrophils, endotoxin, antiviral therapy, granulocyte colonystimulating factor

\section{ЭНАОТОКСИНЕМИЯ ПРИ ПРОТИВОВИРУСНОЙ ТЕРАПИИ ХРОНИЧЕСКОГО ВИРУСНОГО ГЕПАТИТА С И ВОЗМОЖНОСТИ \\ ЕЕ ФАРМАКОАОГИЧЕСКОЙ КОРРЕКЦИИ \\ Н. И. ГЕЙВАНАОВА, А. В. ЯГГОАА, Е. М. БОНААРЕНКО}

У 101 больного с ХВГС определяли содержание эндотоксина в сыворотке крови. Всем пациентам проводилась комбинированная противовирусная терапия (ПВТ): 83 больных получали ПегИФН- $\alpha 2$ (Пегасис) и 18 - препараты ИФН- $\alpha$ короткого действия.

Общее количество лейкоцитов, число нейтрофилов и уровни в крови эндотоксина до начала ПВТ были нормальными. В ходе ПВТ нейтропения II степени развилась у 62 больных (54 пациента, получавших Пегасисе, и 8 - ИФН- $\alpha$ короткого действия). На фоне развития нейтропении начиная с 8 недели отмечалось увеличение содержания в крови эндотоксина у всех пациентов. При этом у больных с нейтропенией уровень эндотоксина был выше, чем у пациентов без нейтропении. Была выявлена обратная связь между уровнем эндотоксина и числом нейтрофилов. Филграстим (Нейпомакс) был применен у 28 пациентов с нейтропенией $<1,0 \times 10^{9} /$ л. На фоне назначения филграстима достоверно уменьшался уровень эндотоксинемии $(p<0,05)$ и улучшалось самочувствие пациентов. Введение филграстима позволило сохранять уровень нейтрофилов не ниже $1,0-1,5 \times 10^{9} / л$ и тем самым предотвращать необходимость снижения дозы интерферонов.

Ключевые слова: хронический вирусный гепатит C, нейтрофилы, эндотоксин, противовирусная терапия, гранулоцитарный колониестимулирующий фактор

\title{
FEASIBILITY OF ALLOCATION OF PERSONS WITH SIGNS PREHYPERTENSION IN PREVENTIVE MEDICAL INVESTIGATION OF STUDENT YOUTH
}

\author{
Evsevyeva M. E., Mistchenko E. A., Rostovtseva M. V., Sergeeva O. V.,
} Galkova I. Yu, Smirnova T. A.

\section{Stavropol State Medical University, Russian Federation}

Evsevyeva Maria, MD, PhD, Professor, Honored Doctor of the Russian Federation, Head of the Student Health Center, Head of Department of Internal Illnesses, Stavropol State Medical University;

tel.: 8(928)3154687; e-mail: evsevieva@mail.ru

Mistchenko Elena, PhD, Assistant of Department of Internal Illnesses, Stavropol State Medical University;

tel.: 8(926)3167244; e-mail:elench@yandex.ru

Rostovtseva Maria, Postgraduate of Department of Internal Illnesses, Stavropol State Medical University;

tel.: 8(926)1919513; e-mail: 1919513@gmail.ru

Sergeeva Oksana, PhD, Docent of Department of Internal

Illnesses, Stavropol State Medical University;

tel.: 8(918)7412289; e-mail: sergeeva0303@rambler.ru

Galkova Ilona, Postgraduate of Department of Internal Illnesses,

Stavropol State Medical University;

tel.: 8(928)2933574; e-mail:ilona-vmc@inbox.ru rterial hypertension $(\mathrm{AH})$ remains one of the most acute problems of modern health care because of the high incidence and significant contribution to the overall structure of mortality and disability population $[1,2,3]$. However, its detection in the early stages in young adults remains unsatisfactory $[4,5]$. In this regard, adequate assessment of high normal blood pressure (HNAD), which relates in accordance with the classification of the Joint National Committee on Detection, Evaluation and Treatment of hypertension USA (ONC 7) prehypertension should call special attention to professionals. Current data 